\title{
Upper crustal structure of Madeira Island revealed from ambient noise tomography
}

\author{
Catarina Matos ${ }^{\mathrm{a}, *}$, Graça Silveira ${ }^{\mathrm{a}, \mathrm{b}}$, Luís Matias a ${ }^{\text {, }}$, Rita Caldeira ${ }^{\text {c,a }}$, M. Luísa Ribeiro ${ }^{\mathrm{c}}$, Nuno A. Dias ${ }^{\text {b,a }}$, \\ Frank Krüger ${ }^{\mathrm{d}}$, Telmo Bento dos Santos ${ }^{\mathrm{c}, \mathrm{a}}$ \\ a Instituto Dom Luiz-IDL, Campo Grande, edifício C8, Piso 3, 1749-016 Lisbon, Portugal \\ b Instituto Superior de Engenharia de Lisboa-ISEL, Rua Conselheiro Emídio Navarro, 1, 1959-007 Lisbon, Portugal \\ c Laboratório Nacional de Energia e Geologia-LNEG, Estrada da Portela, Bairro do Zambujal, 2610-999 Amadora, Portugal \\ d Universität Potsdam-Institut für Erd-und Umweltwissenschaften, Karl-Liebknecht-Str. 24-25, 14476 Potsdam-Golm, Germany
}

\section{A R T I C L E I N F O}

\section{Article history:}

Received 13 November 2014

Accepted 30 March 2015

Available online 7 April 2015

\section{Keywords:}

Madeira island

Volcanic rift zone

Crustal structure

Ambient noise tomography

\begin{abstract}
A B S T R A C T
We present the first image of the Madeira upper crustal structure, using ambient seismic noise tomography. 16 months of ambient noise, recorded in a dense network of 26 seismometers deployed across Madeira, allowed reconstructing Rayleigh wave Green's functions between receivers. Dispersion analysis was performed in the short period band from 1.0 to $4.0 \mathrm{~s}$. Group velocity measurements were regionalized to obtain 2D tomographic images, with a lateral resolution of $2.0 \mathrm{~km}$ in central Madeira. Afterwards, the dispersion curves, extracted from each cell of the 2D group velocity maps, were inverted as a function of depth to obtain a 3D shear wave velocity model of the upper crust, from the surface to a depth of $2.0 \mathrm{~km}$. The obtained 3D velocity model reveals features throughout the island that correlates well with surface geology and island evolution.
\end{abstract}

(c) 2015 Elsevier B.V. All rights reserved.

\section{Introduction}

Madeira Island is an intraplate volcanic island, located in the eastern North Atlantic Ocean, $700 \mathrm{~km}$ west of the Moroccan coast. It is a topographically very heterogeneous island, with an emerged area of $737 \mathrm{~km}^{2}$ and a maximum altitude of $1861 \mathrm{~m}$. It is connected to the Desert islands ( $25 \mathrm{~km}$ to SE) by the $400 \mathrm{~m}$ isobath and to the island of Porto Santo (40 km to NE) by the $3000 \mathrm{~m}$ isobaths (Fig. 1A). These islands are part of a region of raised seafloors that develops towards NNE, roughly tracing the magnetic anomalies up to the African plate limit. The Madeira Abyssal plain limits these hills to the West.

Madeira lies in a region of low seismicity rate $(<40$ events/yr) with events of low to moderate magnitudes $\left(\mathrm{M}_{\mathrm{L}}<4.0\right)$. The earthquake distribution is diffuse and can be seen in Fig. S1, available as an electronic supplement to this paper.

Although not a prominent swell (Ito and van Keken, 2007), the Madeira island lies over a thermal swell (Sleep, 1990) consistent with a large region of mantle upwelling evidenced by a seismic tomography and isotope geochemistry joint study (Hoernle et al., 1995), later supported by an independent isotope geochemistry study (Mata et al., 1998).

\footnotetext{
* Corresponding author at: Instituto Dom Luiz, Campo Grande, Edifício C8, 1749-016 Lisboa, Portugal. Tel.: + 351217500 000x28331; fax: + 351217500807.

E-mail addresses: cpomatos@fc.ul.pt (C. Matos), mdsilveira@fc.ul.pt (G. Silveira), lmmatias@fc.ul.pt (L. Matias), rita.caldeira@lneg.pt (R. Caldeira), luisa.duarte@lneg.pt (M.L. Ribeiro), ndias@adf.isel.pt (N.A. Dias), Frank.Krueger@geo.uni-potsdam.de (F. Krüger), telmo.santos@lneg.pt (T. Bento dos Santos).
}

The island of Madeira figures in the list of worldwide hotspots since (Morgan, 1971; Mata, 1996; Mata and Munhá, 2004; Mata et al., 2013) favored the existence of a mantle plume to explain hotspot volcanism in the region. Other authors, based on field work (Fonseca et al., 1998; Brum da Silveira et al., 2010) suggest that regional tectonics also played an important role in controlling volcanism in the region.

The volcanism in Madeira is characterized by low rates of magma supply. It can be classified as active ( $\sim 0006 \mathrm{Ma})$, although no historical eruptions are documented in the island (Geldmacher and Hoernle, 2000; Geldmacher et al., 2000, 2005; Caldeira et al., 2013). Several authors (e.g. Zbyszewski et al., 1975; Mata et al., 1989, 2013; Geldmacher and Hoernle, 2000; Geldmacher et al., 2000, 2005; Ribeiro and Ramalho, 2009; Brum da Silveira et al., 2010) consider that the geological evolution of the island is divided into three main volcanic stages, presented in Fig. 1B: (1) Emersion phase (5.6-2.5 Ma), comprising the formation of a central volcanic edifice with a E-W oriented rift system, resulted mainly of explosive activity materialized by the $\beta 1$ volcanic complex where pyroclasts predominate over basaltic lava flows; (2) Shield stage (2.5-1.0 Ma), the main building phase that led to the consolidation of the Island, essentially effusive as indicated by the predominance of lava flows over pyroclastic rocks in the $\beta 2, \beta 3$ and $\beta 4$ complexes and (3) Matura phase ( $<1.0 \mathrm{Ma}$ ), that occurred following a period of volcanic inactivity and erosion, consisting in some valley constrained flows ( $\beta 5$ volcanic complex) and recent (6-7 ka) scoria and pyroclastic cones, dikes and plugs. The indicated age intervals were determined using Geochronology dating methods (Mata, 1996; Geldmacher et al., 2000, 2005; Ech-chakrouni, 2004; Klügel et al., 2009). 